\title{
Methods of Domestic Solid Waste Management in Hohoe Urban in the Volta Region
}

\author{
Simon Adom, Wisdom Takramah*, Mavis Pearl Kwabla, Margaret Kweku \\ School of Public Health, University of Health and Allied Sciences, Ho, Ghana \\ Email: *wistaal@yahoo.co.uk
}

Received 20 March 2016; accepted 2 May 2016; published 5 May 2016

Copyright (C) 2016 by authors and Scientific Research Publishing Inc. This work is licensed under the Creative Commons Attribution International License (CC BY). http://creativecommons.org/licenses/by/4.0/

(c) (;) Open Access

\section{Abstract}

Solid waste management has become the greatest public health problem facing many urban and semi-urban areas in Ghana. Great wealth can be generated from wastes if managed effectively but also has high probability of causing serious health and environmental problems if not effectively managed. The study sought to determine factors militating against domestic solid waste management in Hohoe, possible ways of curbing them and also to assess the methods of domestic solid waste management. This study used descriptive cross-sectional survey and structured questionnaire to obtain the required information from respondents. A total number of 403 respondents were recruited into the study. The data collected were entered and analyzed using Statistical Package for Social Sciences version 20. The relationships between socio-demographic characteristics of the respondents and their use or non-use of apt domestic solid waste disposal methods were examined using chi-square analysis. The study found that $44 \%$ of respondents disposed domestic waste into central skip over dustbins. Spilled over of skip over dustbin has caused $8 \%$ of respondents to practice open burning. $7 \%$ dumped on undeveloped building plots, $5 \%$ dumped elsewhere, and $3 \%$ dumped into the river course. About $78 \%$ of respondents reported that mobilization of cleanups was irregular. The result from the study also showed a statistical significant association between practice of domestic solid waste management and religion $\left[\chi^{2}(2,403)=\right.$ 60.9484, $p<0.001, \alpha=5 \%$ ]. About 96\% of Christians practiced good methods of domestic solid waste management compared to $4 \%$ of Muslims. The findings painted a gloomy picture of poor domestic solid waste management practice among the respondents in the study communities.

\section{Keywords}

Solid Waste Management, Environmental Conditions, Infectious Diseases, Methods of Waste Disposal Style, Skip over Dustbin, Hohoe Municipal Assembly, Ghana

\footnotetext{
"Corresponding author.
} 


\section{Introduction}

A research conducted in 2004 defined Solid wastes as non-liquid and nongaseous products of human activities, regarded as being useless [1]. It may possibly take the forms of refuse, garbage and sludge. With that, it is obvious that insanitary disposal of domestic solid waste leads to spread of communicable diseases like cholera, typhoid, worm infestation, poliomyelitis, and environmental degradation in the form of climate change, flood occurrence and destruction of the aesthetic beauty of the environment. These are just few negative effects.

At the moment, cholera disease is endemic in Hohoe municipality. Available statistics at Hohoe Municipal Health Directorate indicated that 328 individuals were infected and 3 people died in 2014. This alarming situation predisposed the general public to be susceptible to cholera disease. Cholera being food and water born disease, it spreads sporadically, because houseflies and domestic animals like fowls, dogs facilitate the spread of vibrio cholerae. The measures to eliminate this menace include cleaning our immediate environment, eating hygienic food and practicing high standard of personal hygiene by way of regular hand washing with soap and avoidance of touching human excrement.

However Cholera, at this 21st century is classified locally in Hohoe, as disease of dirty and poverty. Cholera is still a global threat to human health in developing countries and one of the key indicators of social development which scares foreigners, financial donors and gives bad signal to the international world about infected countries that are not safe for tourism [2]. In Ghana, tourism played a vital role in revenue generation towards nation building.

Globally 2.6 billion people still do not use improved sanitation. 565 million live in sub-Saharan Africa [3]. Large parts of Asia and large majority of countries in sub-Saharan Africa are seriously off-track to meet the Millennium Development Goal set to reduce by half the proportion of people without sustainable access to basic sanitation. And the region had the largest number of countries where less than $50 \%$ of the population had access to improved sanitation. United Nation International Children Education Fund (UNICEF) and World Health Organization (WHO) reports (2008) indicated that only 31\% of the whole population of sub-Saharan Africa (rural and urban combined) had access to "improved" sanitation. West and central Africa had the lowest coverage of improved sanitation in the world [4] [5].

That is less than $30 \%$ of the population of West Africa had access to improved sanitation.

United Nation Human Settlement Programme stated in their report that a city that cannot effectively manage its waste is rarely able to manage more complex services such as health, education, or transportation. The report projected global image of solid waste and annual cost of solid waste management to rise from the current \$205 billion to $\$ 375$ billion [6].

A released on June 6, 2012, solid waste disposal in Ghana titled "What a Waste: A Global Review of Solid Waste Management", indicated that a sharp rise in the amount of garbage generated would come from urban residents between now and 2025 [7]. The report estimated that the amount of municipal solid waste will rise from the current 1.3 billion tonnes per year to 2.2 billion tonnes per year by 2025, with much of the increase coming from rapidly growing cities in developing countries. Also, giving projections, the report indicated that low income countries are expected to generate 213 million tonnes of solid waste a day with the population rising to 676 million by 2025. Lower middle income countries are also projected to generate 956 million tonnes of solid waste per day and its population is predicted to reach 2.08 billion. Waste generation will hit 360 million tonnes per day by 2025 in upper middle income countries with expected population of 619 million. For high income nations, waste generation a day by 2025 will reach 686 million tones and population at 912 million. The report adds that, challenges surrounding municipal solid waste are going to be enormous, on a scale of, if not greater than, the challenges we are currently experiencing with climate.

Developing countries face serious environmental degradation and health risks due to the weakly developed municipal solid waste management system [8] [9]. With open dumped site approach as solid waste management method, this is a primitive stage of solid waste management in many parts of the world. It is one of the most poorly rendered services by municipal authorities in developing countries as the systems applied are unscientific, outdated and inefficient.

A study carried out in 2005 posits that one of the main aspects of concern is the pollution caused to the earth, land, air and water [10]. These conditions are worse in the rainy season because of extreme temperatures, which speed up the rate of bacterial action on biodegradable organic material. Another research conducted in 2009 highlighted that in number of health surveys a wide range of health problems including respiratory systems, irri- 
tation of the skin, eyes and nose, gastrointestinal problems, psychological disorders, and allergies, had been discovered [11].

In addition, dumped sites closer to residential areas were always feeding places for dogs and cats. These pets, together with pests like rodents, carry diseases on them to nearby homes [12].

Ghana's five largest cities Accra, Kumasi, Sekondi-Takoradi, Tamale and Tema account for about 19\% of the total population and their residents generated an estimated 3200 tonnes of solid waste per day [13]. Poor solid wastes management with its immediate and visible impact remains one of the major challenges to the Ministry of Local Government and Rural Development and many chief executives of metropolitans, municipal and district assemblies. Based on projections of the 2010 Population and Housing Census data, the current population of Ghana is estimated to be around 24,658,823. The other urban localities comprising about $34 \%$ of the total population generated in excess of 5000 tonnes of waste each day, $4.8 \%$ of households have their waste collected directly from their dwellings, 7.9\% burn their household refuse and $57.6 \%$ use various household receptacles for storage and send it to designated public dumps, including communal-container sanitary sites. It was reported that $3.9 \%$ of households burry their refuse while $25.9 \%$ dumped at unspecified locations including undeveloped plots, drains, embankment of water courses, rivers, lakes and wetlands. In total, close to $85 \%$ of all refuse generated were currently not collected and disposed of satisfactorily [14].

However, the waste management situations described above does not show any significance change in domestic waste collection and management in Hohoe urban. This has gone to confirm that the practices of solid waste disposal in the 1950s still exist today and the study area is not an exception. It is against this background that this study is developed to examine the various forms of domestic solid waste management methods in Hohoe, urban of the Volta Region, and to offer insight to citizens, government officials, and business people who might want to help address the methods of solid waste managerial crisis in Hohoe urban council.

\section{Materials and Methods}

\subsection{Study Area}

Hohoe, urban being the study area is consisted of 5 communities as follows Bla, Kpeme, Abansi, Ahador and Torkorni. These 5 communities are located at the middle part of Hohoe municipality and it covered geographical area of $37.86 \mathrm{sqkm}$. The municipality is also situated at the middle part of Volta Region; there are about 7172 houses with an average urban household size of 4.3 and population size of 32,000 people in Hohoe urban. The Municipality Shares boundaries with Afadjato District to the north, to the south with South Dayi District, Ho Municipal and Ho West District respectively, to the east with the Republic of Togo and to the west with Kpandu Municipality. The status of Hohoe town in the national matrix of settlements hierarchy and grading is grade 2. The Administrative Capital of the Municipality is Hohoe and the main occupation being entrepreneurship and white color jobs. Reports at Zoom Lion Hohoe specified that 8 tonnes of solid waste generated each day and 5 tonnes managed sanitarily although skip over waste containers are observed overflown with solid waste in the suburb.

\subsection{Study Design}

Descriptive cross-sectional survey was used in this study. A comprehensive and structured questionnaire was used to elicit the required information from the respondents. Interviewer or face to face mode of administration was employed to gather information on demographic characteristics, methods of domestic solid waste disposal, attitude and perception towards domestic solid waste, prioritization of domestic solid waste management in improving public health and organization of communal labour.

\subsection{Sample Size Determination}

Formula for sample size determination as stated below:

$$
n=\frac{Z_{\frac{\alpha}{2}}^{2} p(1-P)}{e^{2}} \text { Source: Cochran W. G. (1977) }
$$

where: $n$ is the minimum sample size, 
$Z$ is $z$ statistics for a confidence level of $95 \%$,

$e$ is the margin of error.

$P$ is the estimated proportion of households involved in domestic solid waste management. Therefore, using a prevalence rate of $25 \%$ of individuals households involved in domestic solid waste management in Hohoe urban, at a confidence level of $95 \%(z=1.96)$, with a margin of error of $0.05(5 \%)$, an expected sample size of 384 was obtained. This figure (384) is adjusted upwards by $5 \%$ non-response rate, to compensate for non-responses which gave a sample size of 403 .

$$
\begin{gathered}
n=\left(1.96^{2} \times 0.5(1-0.5)\right) / 0.05^{2} \\
n=3.8416 \times 0.05 \times 0.05 / 0.0025 \\
n=384.16
\end{gathered}
$$

Addition of non-response rate of $5 \%$, gives $19+384=403$.

Thus 403 household members were recruited to participate in the study.

\subsection{Sampling Method}

Expanded Programme for Immunization (EPI) cluster modified sampling method was used since the list of households was not available.

Steps:

1) Each community selected conveniently was divided into sectors.

2) One sector was selected at random to identify central point.

3) Spin pointed device and counted the houses by following the pointed device to the boundaries and numbered the houses on paper nicely whiles first house was picked at random as the starting point.

4) If there are two or three households in a selected house only one household was drawn at random and also only one person in the household was randomly selected to represent all the households' members.

5) In case there are 4 or more households in a house selected, two households were drawn at random and only one person was randomly selected in each household to represent all household members.

6) After interviewing a respondent in a selected house, the next house closest to the previously selected house was selected for the study. This procedure continued until the required sample size was obtained.

\subsection{Data Collection Procedure}

Both primary and secondary data were collected. Structured questionnaire was administered to collect primary data from the participants selected at random from households randomly chosen for the study. Secondary data from journal, books, periodicals and other relevant published literature were collected.

\subsection{Data Analysis}

The data collected were entered and analyzed using Statistical Package for Social Sciences (SPSS) version 20. Percentages or means and standard deviations were computed for baseline characteristics of respondents. Cross tabulations and chi square analysis that identified important relationships between categorical variables were done. The relationship between socio-demographic characteristics of the respondents and their use or non-use of appropriate waste management method were examined using logistic regression analysis, by computing odds ratio at $95 \%$ confidence level. A p-value $<0.05$ were considered as statistical significance.

\subsection{Ethical Issues}

Ethical approval for the study was sought from the Ghana Health Service Ethics Review Committee. Every respondent was well informed prior to the interview that, they are under no obligation to take part, they can withdraw at any time and all responses were treated with paramount confidentiality. Respondents were also assured that under no condition whatsoever their names or any other contacts be linked to the data analysis and dissemination of the findings of the study. Storage, analysis and reporting of all data were done in formats that do not revealed the identity of the respondents. This was done by using identification codes instead of names in the analysis and reporting process. 


\section{Results}

A total number of 403 respondents participated in the study. The study results show that 314 (77.9\%) of the respondents practiced good methods of domestic solid waste management (dumped into central dustbin, dumped into a household dustbin) whilst 89 (22.1\%) of them practiced bad methods of domestic solid waste management (open dumped, dumped elsewhere, dumped into river course, dumped on undeveloped plot and open burning) (Table 1).

\subsection{Demographic Characteristics and Practice of Domestic Solid Waste Management}

Table 1 indicates methods of domestic solid waste management being practiced and demographic characteristics including age, occupation, ethnicity, religion, sex, educational level and marital status. About $96 \%$ of Christians

Table 1. Demographic data and practice of domestic solid waste management.

\begin{tabular}{|c|c|c|c|c|c|}
\hline \multirow{2}{*}{\multicolumn{2}{|c|}{ Variables }} & \multicolumn{2}{|c|}{ Practice of Domestic Solid Waste Management } & \multirow{2}{*}{$\begin{array}{c}\text { Total (\%) } \\
\text { N = 403 (\%) }\end{array}$} & \multirow{2}{*}{ Chi2/P-Value } \\
\hline & & \multirow{2}{*}{$\begin{array}{c}\text { Good (\%) } \mathbf{n}=\mathbf{3 1 4}(\%) \\
68(21.66)\end{array}$} & \multirow{2}{*}{$\begin{array}{c}\text { Bad (\%) } \mathbf{n}=\mathbf{8 9}(\mathbf{\%}) \\
23(25.84)\end{array}$} & & \\
\hline \multirow{4}{*}{ Age } & 15 - 29 yrs. & & & 91 (22.58) & \multirow{4}{*}{ 6.3008/0.098 } \\
\hline & 30 - 39 yrs. & 87 (27.71) & $15(16.85)$ & $102(25.31)$ & \\
\hline & $40-49$ yrs. & $89(28.34)$ & $34(38.20)$ & $123(30.52)$ & \\
\hline & $50+$ yrs. & 70 (22.29) & 17 (19.10) & 87 (21.59) & \\
\hline \multirow{6}{*}{ Occupation } & Farmer & 31 (9.87) & $18(20.22)$ & 49 (12.16) & \multirow{6}{*}{$13.0369 / 0.023$} \\
\hline & Trader & 200 ( 63.69) & 45 (50.53) & $24(60.76)$ & \\
\hline & Student & $20(6.35)$ & $7(7.87)$ & $27(6.70)$ & \\
\hline & Unemployed & 42 (13.38) & $17(19.10)$ & 59 (14.64) & \\
\hline & Employed & 10 (3.18) & $0(0.00)$ & $10(2.48)$ & \\
\hline & Others & $11(3.50)$ & $2(2.25)$ & $13(3.23)$ & \\
\hline \multirow{3}{*}{ Ethnic Group } & Ewe & 273 (86.94) & 59 (66.29) & 332 (82.38) & \multirow{3}{*}{$26.6275 / 0.0001$} \\
\hline & Hausa & $17(5.41)$ & $20(22.47)$ & 37 (9.18) & \\
\hline & Akan & $24(7.64)$ & $10(11.24)$ & $34(8.44)$ & \\
\hline \multirow{3}{*}{ Religion } & Christian & $302(96.1)$ & $61(68.54)$ & 363 (90.07) & \multirow{3}{*}{$60.9484 / 0.0001$} \\
\hline & Moslem & $12(3.82)$ & 25 (28.09) & 37 (9.18) & \\
\hline & Traditionalist & $0(0.00)$ & $3(3.37)$ & $3(0.74)$ & \\
\hline \multirow{2}{*}{ Sex } & Male & $90(28.66)$ & $33(37.08)$ & $123(30.52)$ & \multirow{2}{*}{$2.3163 / 0.128$} \\
\hline & Female & $224(71.34)$ & $56(62.92)$ & $280(69.48)$ & \\
\hline \multirow{4}{*}{ Educational Level } & Primary & 117 (37.26) & $26(29.21)$ & $143(35.48)$ & \multirow{5}{*}{$6.442 / 0.168$} \\
\hline & Secondary & $141(44.90)$ & $45(50.56)$ & $186(46.15)$ & \\
\hline & Tertiary & $22(7.01)$ & $12(13.48)$ & $34(8.44)$ & \\
\hline & JSS & $4(1.27)$ & $1(1.12)$ & $5(1.24)$ & \\
\hline \multirow{5}{*}{ Marital Status } & None & 30 (9.55) & $5(5.62)$ & 35 (8.68) & \\
\hline & Single & $89(28.34)$ & $22(24.72)$ & $111(27.54)$ & \multirow[t]{4}{*}{$2.5529 / 0.466$} \\
\hline & Married & 197 (62.74) & $62(69.66)$ & 259 (64.27) & \\
\hline & Divorce & $10(3.18)$ & $3(3.37)$ & $13(3.23)$ & \\
\hline & Separated & 18 (5.73) & $2(2.25)$ & $20(4.96)$ & \\
\hline
\end{tabular}


were reported to have practiced good methods of domestic solid waste management as compared to $4 \%$ of Muslim. Sixty four percent (64\%) of traders practiced good methods of domestic solid waste management compared to $10 \%$ of farmers. In Table 1 , a chi square test suggests a significant association between occupation and methods of domestic solid waste management being practiced $\left(\chi^{2}(5,403)=13.0369, p=0.023, \alpha=5 \%\right)$. A significant association has also been established between ethnic groups and methods of domestic solid waste management being practiced $\left(\chi^{2}(2,403)=26.6275, p<0.0001, \alpha=5 \%\right)$. Table 1 also indicates a strong association between religion and methods of domestic solid waste management $\left(\chi^{2}(2,403)=60.9484, p<0.0001, \alpha=5 \%\right)$. However, there is not enough evidence to impute a statistical significant association between methods of domestic solid waste management and sex, educational level, marital status and age.

\subsection{Attitude and Perception towards Domestic Solid Waste}

In Figure 1, the pie chart indicates that about $94 \%$ of respondents clean their immediate surroundings daily where as $6 \%$ of participants clean their environment weekly.

The pie chart below exhibits the importance for prioritizing safe methods of household solid waste management to promote health. Exactly $98 \%$ of respondents admitted to prioritizing domestic solid waste management as a way to improve public health whilst $2 \%$ thought otherwise.

In Figure 2, the bar chart illustrates various methods of domestic solid waste management practiced by respondents. About $45 \%$ of respondents dumped domestic waste into central dustbins, almost $29 \%$ of respondents' dumped solid waste into household dustbins, compared with only $3 \%$ of participants who dumped waste into the river course.

The pie chart in Figure 4 shows the perception of respondents towards domestic solid waste management. About $38 \%$ of participants rated domestic solid waste management methods as fair, exactly $24 \%$ of them rated waste management methods as good whiles almost $11 \%$ of participants believed the methods were in bad state.

\subsection{Community Participation towards Domestic Solid Waste Management and Hygienic Conditions}

In Figure 5, the bar chart indicates how often cleanup is organized in the community. About $78 \%$ of respon-
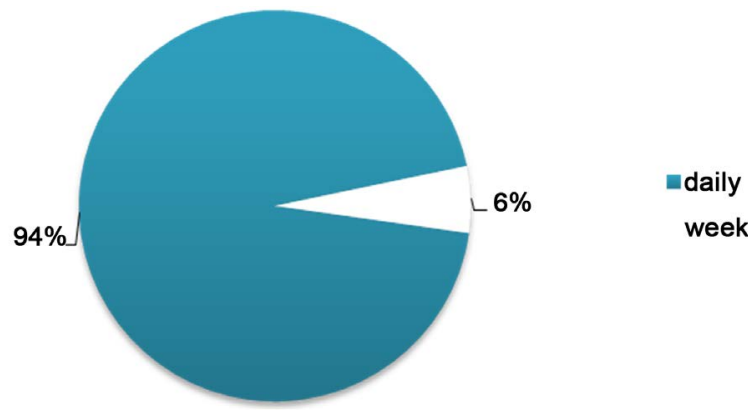

weekly

Figure 1. Cleanliness of surroundings.

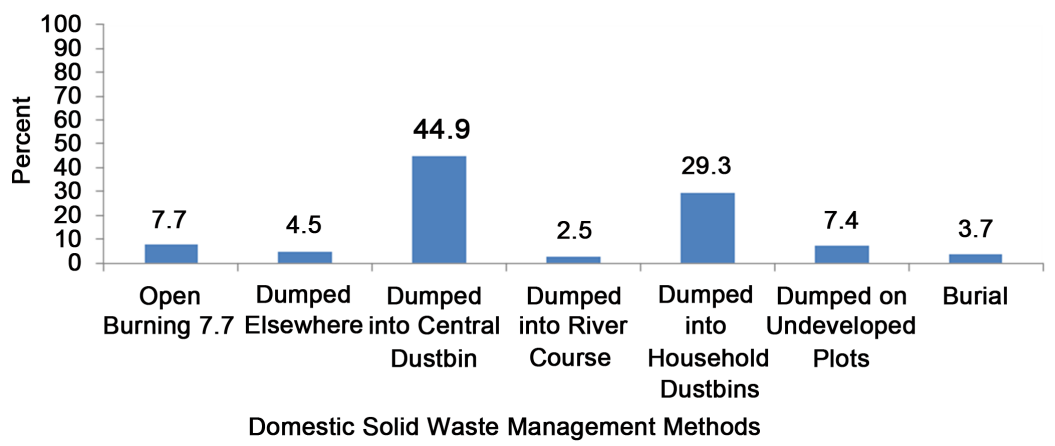

Figure 2. Methods of solid waste management. 
dents confirmed that cleanups were irregularly mobilized, whiles about $15 \%$ respondents said cleanups were organized once in six month and approximately $0.25 \%$ participants reported that cleanups were scheduled once in every weeks.

Figure 6 Illustrates whether cleanups were organized and undertaken in the community. Exactly 96\% of participants reported that cleanups were organized and implemented in the community, but $4 \%$ of respondents said that cleanups were not organized in their communities.

\section{Discussion}

This section discusses series of contemporary issues in relation to Methods of Domestic Solid Waste Management by comparing the findings of this study and the literature reviewed.

The research revealed a significant relationship between ethnicity and practice of domestic solid waste management where about $86 \%$ of Ewes practiced good methods of domestic solid waste management compared to 5\% of Muslim who practiced good methods (Table 1). The result from the study also show a statistical significant association between practice of domestic solid waste management and religion, where $96 \%$ of Christians and only $4 \%$ of Moslems practiced good methods of domestic solid waste management (Table 1). These findings with respect to only $4 \%$ of Moslems practicing good methods of domestic solid waste management agreed with the general perception of insanitary conditions among Islamic communities leading to environmental pollution and contamination.

A study conducted in 2007 to investigate Gender differences in Egyptian consumers' green purchase behavior found a positive relationship between education, environmental consciousness and ecological knowledge [15]. Even though the researcher did not consider environmental consciousness and ecological knowledge in this study, it was established that $30 \%$ of those with no (none) education practiced bad methods of solid waste disposal methods (Table 1).

Prioritizing domestic solid waste management as a way to improve public health is paramount as reported by 98\% of the respondents (Figure 3). This means that majority of the respondents are conscious of the fact that good solid waste management practice is the surest way to help improve sanitation, thus preventing infectious diseases in the communities. Perception of solid waste management among the respondents is discouraging as about $65 \%$ of the respondents rated solid waste management as bad as compared to $24 \%$ who rated it as good (Figure 4). A lot of work needs to be done to improve solid waste management.

The study also reveals that $94 \%$ of respondents clean their immediate surroundings daily where as $6 \%$ clean their environment weekly (Figure 1). This statistic looks good and encouraging. Activities of Zoom Lion Ghana Limited which is a private organization working in collaboration with the Environmental health units to ensure a clean Ghana may be attributable to this result.

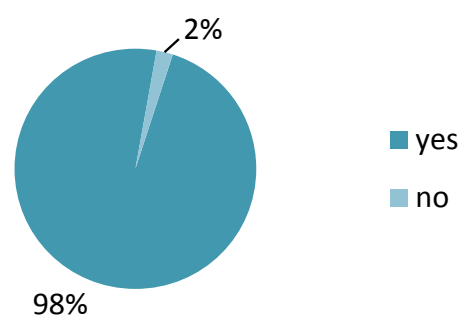

Figure 3. Prioritization of domestic solid waste management in improving public health.

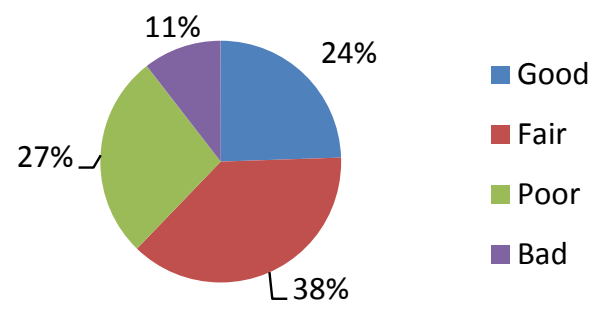

Figure 4. Perception of solid waste management. 
When the researcher quizzed the respondents about how often clean up exercise was organized in the community, 78\% of them reported that clean ups were irregularly mobilized (Figure 5). To this end, it is very important to intensify keep Ghana clean campaign under the auspices of the Ministry of Local Government and Rural Development. However, Exactly 96\% of respondents reported that clean ups were organized and implemented in the community (Figure 6).

According to [16] incinerators have the capacity to reduce the volume of waste drastically, up to nine fold than any other method. Incineration is the burning of wastes under controlled conditions, carried out in an enclosed chamber. However, in this study burning of domestic solid waste was done in unenclosed place without any control as one of the crude methods of solid waste management. It was observed that about $8 \%$ of respondents practiced burning of domestic solid waste as a method in order to reduce the size and volume of domestic solid waste, but this approach could cause environmental pollution and fire outbreaks in the study area.

Furthermore, a study carried out in in Nigeria displayed the methods of solid waste disposal including dumping of waste in gutters, drains, by roadside, unauthorized dumping sites and stream channels during raining season and burning of wastes on unapproved dumping sites during the dry season [17]. The findings of this study established that the above mentioned methods were also practiced by the respondents. It was found that about $45 \%$ of respondents' dumped domestic solid waste into central dust bins, $29 \%$ of them dumped waste into household dustbins, $8 \%$ practiced open burning method, $7 \%$ dumped solid waste on undeveloped building plots, $4 \%$ practiced burial, $5 \%$ dumped domestic solid waste elsewhere in the community, and only $3 \%$ dumped household waste into the river course (Figure 2).

The undesirable and bad methods of domestic solid waste management like open burning could lead to environmental pollution, smoke nuisance, respiratory and allergic conditions for asthmatic clients and the general public. The bad methods of domestic solid waste management also may cause the degradation of climatic conditions where household electronic items like used touch light batteries and empty insecticides containers and weedicides are burnt in the community, it gradually depletes the ozone layer, hence the exposure of strong sun rays to the earth layer causing skin irritation problems, as well as delay in rainfall patterns which negatively affects the production of food crops leading to poverty and hunger.

Again dumping of domestic solid waste on undeveloped building plot could also be an eyesore, harboring and serving as breeding ground for reptiles, rodents and cockroaches which would bite and inflict harm on community members, whiles rodent and cockroaches' infestation could cause destruction of valid properties like clothes and books [18].

A study by [19] revealed that Ghanaian cities are experiencing worsening solid waste situations which the municipal governments lack the capacities in terms of financial, logistical and human resources to cope with the situation and proposed privatization and political commitment to urban environmental management as the solution. Though the Government of Ghana has implemented initiatives such as the nationwide clean-up campaign every first Saturday of the month and engagement of the private sector, it appears this is not yielding the needed result as can be seen in the results of this study. The burial methods of domestic solid waste management in the

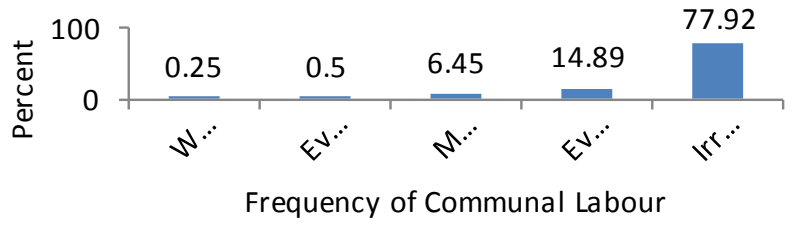

Figure 5. Frequency of communal labour.

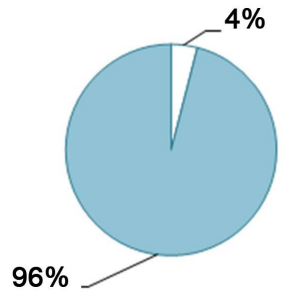


study is not done in a standardized form rather haphazardly, this was identified to be one of the bad methods in existence in Hohoe urban, where dogs, fowls and other domestic animals exhumed waste causing flies nuisance and good ground for spread of diseases. Land intended for house building are damaged which needs to be reclaimed before use for it purpose.

In addition, few respondents dump domestic solid waste into river cause, which is very bad method practiced, because the stream which is contaminated with solid waste is used as potable water for upstream community members which could expose them to communicable diseases like cholera, typhoid and other which does not promote health of such people.

All these could put pressure on national health insurance scheme and the government of Ghana as funds intended for human resource and physical infrastructure development will be diverted to addressing health issues related to insanitary conditions.

\section{Conclusions}

It is imperative to outline the various methods of solid waste management identified in this study.

It would be unfair concluding without making reference to the methods used by the respondents to manage solid waste in Hohoe Urban Council. It is worth noting the fact that crude methods of domestic solid waste are still being practiced in this $21^{\text {st }}$ century. $8 \%$ practice open burning method, $7 \%$ dump solid waste on undeveloped building plots, $4 \%$ practice insanitary burial, $5 \%$ dump domestic solid waste elsewhere in the community, and $3 \%$ dump household waste into the river course, polluting, degrading and destroying the aesthetic beauty of natural and built environment.

In addition, almost $11 \%$ of participants rated the methods of domestic solid waste management as bad and outmoded. This clearly revealed the deficit and short fall of adequate and satisfactory sanitary methods of domestic solid waste management.

\section{Recommendation}

This section provides series of proposed recommendations and remarks regarding possible methods of domestic solid waste management and interventions that should be considered by policy makers and environmental health department:

- Assembly should outline modalities for distributing current domestic solid waste dustbins placed at the forecourt of Hohoe Municipal Assembly to interested households in order to promote sanitary management of solid waste.

- Assembly should design programmes to frequently remove domestic solid waste from the entire Hohoe urban council based on the type and volume of waste generated to avoid spillage of solid waste in central dustbins, also promote collaboration between communities to practice good management of domestic solid waste methods.

- The Municipal Assembly should provide one solid waste recycle machine to reduce the amount of domestic solid waste generated in the study area to eliminate air, ground and water pollution and reuse recycled materials.

- Municipal Assembly should support Environmental Health and Sanitation Unit with measuring tools and amenities to quantify the types of domestic solid waste produced annually so as to commend adoption of new strategic plans to the current daily increasing population to facilitate effective and efficient methods of domestic solid waste management. The Municipal Assembly should provide one solid waste recycle machine to reduce the amount of domestic solid waste generated in the study area to eliminate air, ground and water pollution and reuse recycled materials.

- The management of Zoom Lion Ghana Limited in Hohoe urban council should adequately transport domestic solid waste to final disposal site with adequate fitting cover material to avoid scattering and flying of solid waste in communities whiles in transit.

- The monthly communal Labour Day should rather be devolved where management at grass root level would rather be a lead for the programme in the Municipal Assembly where norms and culture of the people would be highly considered before observing a convenient day for clean-ups that would lure everybody to participate.

- The executive committee of Hohoe Municipal Assembly should put strategic plans in place for capacity 
building to staff of environmental health and sanitation unit, and institutions responsible for domestic solid waste management. Also arrange partnerships so as to endow them with resources like adequate and fitting domestic dustbins, trucks, tractors, compactors to improved management of solid waste to avoid artificial disasters and outbreak of cholera among the populace in Hohoe Municipal Assembly and its environs.

- Municipal Assembly should prompt Zoom Lion Ghana Limited to maintain the only solid waste collection hydraulic compactor to be road wealthy all the time to avoid accumulation of domestic solid waste on various premises and spillage of solid waste in houses, also management of Zoom Lion should provide an additional refuse tract to augment management of domestic solid waste in the study area.

\section{Acknowledgements}

I am grateful to God Almighty for given me the wisdom to complete the project work successfully. Special thanks go to my supervisor, Mr. Wisdom Kwami Takramah, a lecturer at school of public health Hohoe, University of Health and Allied Sciences for providing me with excellent advice during the processes of my project work formulation and realization. I appreciate his serious interest in my work and I am thankful for his comments about how to improve my research activities in the future. I would also like to express my acknowledgment to my only two brothers Mr. Micheal Komla Boyson Adom who is an entrepreneur in Tema and Frank Kosi Anani Adom who is a charted accountant and senior lecture in Dominion University Accra. My heartfelt sincere thanks go to all academic and non-academic staff of school of Public health Hohoe, University of Health and Allied Sciences for their invaluable support during the project work.

\section{Conflict of Interest}

All authors report no conflict of interest in this study.

\section{Authors' Contributions}

SA worked on the proposal and carried out the research as part of project work for the award of Bachelor in Public Health (BPH). WKT gave advice and direction and also performed analysis. The write up was done by SA and MPK. Proof reading was done by MPK and MK.

\section{References}

[1] Leton, T.G. and Omotosho, O. (2004) Landfill Operations in the Niger Delta Region of Nigeria. Engineering Geology, 73, 171-177. http://dx.doi.org/10.1016/j.enggeo.2003.12.006

[2] WHO (2006) Cholera as a Global Threat. WHO, Geneva.

[3] Mehta, L. and Movik, S. (201 1) Shit Matters: The Potential of Community-Led p. 1-17.

[4] UNICEF and WHO (2008) Progress Towards the MDG Sanitation Target Source. UNICEF and WHO, Los Angeles, Geneva.

[5] Pradhan, S.K., Opuni, S.C., Fosu, M. and Drechsel, P. (2013) Municipal Organic Waste Management: Challenges and Opportunities in Tamale, Ghana. http://wedc.lboro.ac.uk/resources/conference/36/Pradhan-1678.pdf

[6] Abdulla, F., Qdais, H.A. and Rabi, A. (2008) Site Investigation on Medical Waste Management. Waste Management \& Research, 29, 442-450.

[7] World Bank (2012) What a Waste: A Global Review of Solid Waste Management. https://www.ghanabusinessnews.com/2012/06/08/world-bank-predicts-annual-cost-of-treating-solid-waste-rising-to-37 5b-by-2025/

[8] Nguyen, P.T. (2011) Assessment of Plastics Waste Generation and Its Potential Recycling of Household Waste in Can City, Vietnam. Environmental Monitoring and Assessment, 175, 23-35.

[9] Oteng-Ababio, M., Arguello, J.E.M. and Gabbay, O. (2013) Solid Waste Management in African Cities: Sorting the Facts from the Fads in Accra, Ghana. Habitat International, 39, 96-104. http://dx.doi.org/10.1016/j.habitatint.2012.10.010

[10] Boardi, O. and Kuitunen, M. (2012) Environmental and Health Impacts of Household Solid Waste and Disposal Practices in the Third World Cities: The Case of Accra Metropolitan Area, Ghana. Journal of Environmental Health, 68, 32-36.

[11] Gouveia, N. and Do Prado, R.R. (2009) Health Risks in Areas Close to Urban Solid Waste Landfill Sites. Revista de 
Saúde Pública, 44, 859-866.

[12] Miezah, K., Obiri-Danso, K., Kádár, Z., Fei-Baffoe, B. and Mensah, M.Y. (2015) Municipal Solid Waste Characterization and Quantification as a Measure towards Effective Waste Management in Ghana. Waste Management, 46, 15-27. http://dx.doi.org/10.1016/j.wasman.2015.09.009

[13] Ministry of Local Government and Rural Development (2010) National Environmental Sanitation Strategy and Action Plan. http://wcghana.com/reports/national_environmental_sanitation_strategy_and_action_plan.pdf

[14] Ofori-Boateng, C., Lee, K.T. and Mensah, M. (2013) The Prospects of Electricity Generation from Municipal Solid Waste (MSW) in Ghana: A Better Waste Management Option. Fuel Processing Technology, 110, 94-102. http://dx.doi.org/10.1016/j.fuproc.2012.11.008

[15] Mostafa, M.M. (2007) Gender Differences in Egyptian Consumers' Green Purchase Behavior: The Effects of Environmental Knowledge, Concern and Attitude. International Journal of Consumer Studies, 31, 220-229. http://dx.doi.org/10.1111/j.1470-6431.2006.00523.x

[16] Hui, Y., Li'ao, W., Fenwei, S. and Gang, H. (2006) Urban Solid Waste Management in Chongqing. Challenges and Opportunities Waste Management, 26, 1052-1062.

[17] Momoh, J.J. and Oladebeye, D.H. (2010) Assessment of Awareness of Attitude and Willingness of People to Participate in Household Solid. Journal of Applied Sciences in Environmental Sanitation, 5, 93.

[18] Oteng-Ababio, M. (2011) Missing Links in Solid Waste Management in the Greater Accra Metropolitan Area in Ghana. Geographical Journal, 76, 551-560. http://dx.doi.org/10.1007/s10708-010-9363-9

[19] Baabereyir, A. (2009) Urban Environmental Problems in Ghana: A Case Study of Social and Environmental Injustice in Solid Waste Management in Accra and Sekondi-Takoradi [Internet]. University of Nottingham, Nottingham. http://eprints.nottingham.ac.uk/10847/ 